\title{
Roles of Mineralogical Phases in Aqueous Carbonation of Steelmaking Slag
}

\author{
Huining Zhang ${ }^{1, *}$, Yongming Lu ${ }^{2}$, Jianhong Dong ${ }^{1}$, Lei Gan ${ }^{1}$ and Zhifang Tong ${ }^{1}$ \\ 1 School of Metallurgy and Chemical Engineering, Jiangxi University of Science and Technology, \\ Ganzhou 341000, China; hong620421@126.com (J.D.); ganlei2005@163.com (L.G.); \\ tongzhifang1998@126.com (Z.T.) \\ 2 State Key Laboratory of Hybrid ProcessIndustry Automation System and Equipment Technology, \\ Automation Research and Design Institute of Metallurgical Industry, China Iron and Steel Research \\ Institute Group, Beijing 100071, China; luyongming2001@163.com \\ * Correspondence: zhanghuining2008@126.com; Tel.: +86-182-7073-6836
}

Academic Editor: Corby G. Anderson

Received: 29 March 2016; Accepted: 5 May 2016; Published: 18 May 2016

\begin{abstract}
Mineralogical phases of steelmaking slags have significant influences on the carbonation of the slags. In this paper, the effects of temperature and reaction time on the conversion of calcium-related phases and the carbonation degree of a slag sample were studied. The experimental conditions were a liquid-to-solid ratio of $20 \mathrm{~mL} / \mathrm{g}$, a carbon dioxide flow rate of $1 \mathrm{~L} / \mathrm{min}$ and a slag particle size of 38-75 $\mu \mathrm{m}$. The results show that the optimum carbonation temperature and reaction time are $60{ }^{\circ} \mathrm{C}$ and $90 \mathrm{~min}$, respectively, and calcite phase content is about $26.78 \%$ while the conversion rates of $\mathrm{Ca}_{3} \mathrm{Al}_{2} \mathrm{O}_{6}, \mathrm{CaSiO}_{3}, \mathrm{Ca}_{2} \mathrm{SiO}_{4}$ and free $\mathrm{CaO}$ are about $40 \%, 42.46 \%, 51 \%$ and $100 \%$, respectively, and the carbon dioxide sequestration efficiency is about $170 \mathrm{~g} / \mathrm{kg}$ slag.
\end{abstract}

Keywords: steelmaking slag; mineralogical phase content; carbonation degree; conversion rate

\section{Introduction}

As known to us, the generation rate of steelmaking slag is about $10 \%-15 \%$ of crude steel production. In China, there are more than 100 million tons of steelmaking slags stored on the ground. Steelmaking slag has been accumulated for a long time without consideration. This not only wastes valuable resources, but also causes some threats. For example, heavy metal in slag can contaminate groundwater. Thus, the development of utilization technologies of steelmaking slag has garnered more attention recently.

The idea of slag carbonation comes from the mineral carbonation firstly proposed by Seifritz [1] and then developed by Lackner [2]. $\mathrm{CO}_{2}$ is hardly released from carbonation products after mineralizing because they are thermodynamically stable [2,3]. Furthermore, steelmaking slag is rich in calcium and magnesium, and naturally, steelmaking slag can be a better $\mathrm{CO}_{2}$ adsorption carrier. The utilization of slag has some advantages including lower cost and minimal environmental impacts through pH-adjustment [4,5].

The existing dominant slag carbonation process has three advantages. Firstly, greenhouse gas carbon dioxide can be sequestrated permanently. Secondly, the reaction process is helpful for improving the stability of slag for construction materials, because active mineralogical phases containing calcium stay stable in the form of calcium carbonate. Lastly, calcium carbonate precipitates in slag particles surface, and the coated surface after carbonation hinders the heavy metal leaching process. 
In previous works, the effect of experimental parameters such as the ratio of liquid to solid ( $L / S$ ratio), temperature, particle size, stirring intensity, etc., on carbonation efficiency and the slag carbonation mechanism were analyzed when slag was dissolved in water [6,7]. In order to improve the carbonation efficiency, conditions such as higher reaction pressure [8-12] and an acid leaching agent [13-15] are adopted. Previous researchers focused on the total carbonation degree of steelmaking slag in their research. The effects of mineralogical phases containing calcium on the carbonation degree were less referred to in literature. In order to analyze the $\mathrm{CO}_{2}$-binding mineralogical phases' activity with carbon dioxide when slag is applied for carbon dioxide sequestration, in this paper the effects of the main mineralogical phases containing calcium on the carbonation degree have been studied by quantitative X-ray diffraction (XRD) collaborating with X-ray fluorescence spectroscopy (XFR) analysis, and the effects of temperature and time on the conversion rate of mineralogical phases have been analyzed.

\section{Material and Methods}

\subsection{Sample Characterization}

A steelmaking slag sample was taken from a Chinese steel plant (Baosteel, Shanghai, China). The steelmaking slag sample was ground in a ball mill. Chemical composition of the slag sample was analyzed and is presented in Table 1 . It can be seen that calcium oxide content nearly counts for $55.3 \%$, magnesium oxide content is less than $10 \%$, silicon dioxide content of the steelmaking slag is more than $10 \%$, and aluminum oxide is about $30 \%$. Quantitative X-ray diffraction (XRD) test for steelmaking slag was conducted. XRD analysis in a Dron-3M diffractometer (Shimadzu Ltd., Tokyo, Japan) using $\mathrm{Ni}$-filtered $\mathrm{Cu}-\mathrm{K} \alpha$ radiation, powdered non-oriented preparations was made. Diffractograms were digitally registered and analyzed by Sirquant code [16] using full-profile Rietveld analysis [17].

Table 1. Chemical composition of the slag sample, wt. \%.

\begin{tabular}{cccccccc}
\hline TFe & $\mathrm{MFe}$ & $\mathrm{FeO}$ & $\mathrm{CaO}$ & $\mathrm{MgO}$ & $\mathrm{SiO}_{2}$ & $\mathrm{Al}_{2} \mathrm{O}_{3}$ & $\mathrm{MnO}$ \\
\hline 0.55 & $<0.50$ & $<0.10$ & 55.3 & 5.64 & 8.00 & 30.0 & 0.41 \\
\hline
\end{tabular}

Specific surface area (SSA) was estimated with BET method at Quanta chrome instruments Autosorb (Automated Gas Sorption1-Win, Version 1.50, CostechMicroanalytical Ltd., Beijing, China), 0.5-1.5 g steelmaking slag with different particle sizes was applied for testing, Nitrogen gas was used for analyzing gas, and analyzing time was set for $200 \mathrm{~min}$, outgas temperature was controlled at $350{ }^{\circ} \mathrm{C}$, and liquid density was $8080 \mathrm{~kg} / \mathrm{m}^{3}$. Scanning electron microscope (SEM) JSM-6301F (JEOL Ltd., Tokyo, Japan) was used for slag surface observations before and after carbonation process.

\subsection{Experimental Setup}

The carbonation degree of the steelmaking slag was investigated at room temperature and under normal atmosphere, and the experimental apparatus is displayed in Figure 1. The experimental apparatus includes measurement and control of temperature and $\mathrm{pH}$ measurement. The liquid-to-solid ratio was set up as $20 \mathrm{~mL} / \mathrm{g}$, and the sample weight was $5 \mathrm{~g}$ each time.

The reactor was sealed with preservation film for avoiding solution evaporation; the initial time is obtained when the temperature reached the target temperature. When experiments began, $\mathrm{CO}_{2}$ gas at a predetermined flow rate was blown into the reactor. The experimental conditions are presented in Table 2. The temperature varied among $25^{\circ} \mathrm{C}, 40^{\circ} \mathrm{C}, 60^{\circ} \mathrm{C}$, and $90^{\circ} \mathrm{C}$, the reaction time changed among $30 \mathrm{~min}, 60 \mathrm{~min}, 90 \mathrm{~min}, 120 \mathrm{~min}$ and $180 \mathrm{~min}$, and $\mathrm{CO}_{2}$ flow rate was kept at $1 \mathrm{~L} / \mathrm{min}$. 


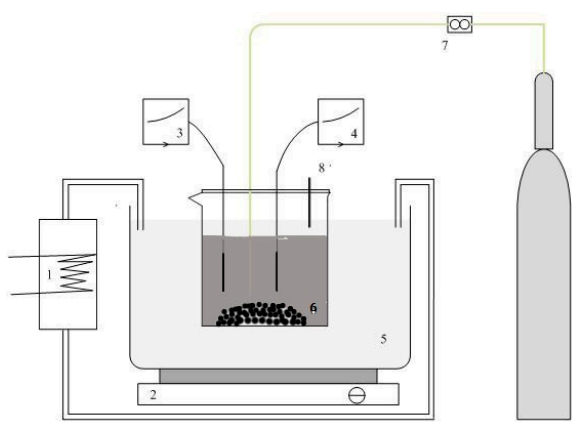

Figure 1. Schematic diagram of steelmaking slag carbonation process: (1) temperature controller; (2) magnetic stirrer; (3) pH reader; (4) temperature electrode; (5) heated water; (6) leaching solution; (7) flow meter; (8) gas exit.

Table 2. Arrangement of carbonation experiment.

\begin{tabular}{cccccc}
\hline Test No. & Temp $\left({ }^{\circ} \mathbf{C}\right)$ & Time $(\mathbf{m i n})$ & Test No. & Temp $\left({ }^{\circ} \mathbf{C}\right)$ & Time $(\mathbf{m i n})$ \\
\hline 1 & 25 & 30 & 11 & 60 & 60 \\
2 & 25 & 60 & 12 & 60 & 90 \\
3 & 25 & 90 & 13 & 60 & 120 \\
4 & 25 & 120 & 14 & 60 & 180 \\
5 & 25 & 180 & 15 & 90 & 30 \\
6 & 40 & 30 & 16 & 90 & 60 \\
7 & 40 & 90 & 17 & 90 & 90 \\
8 & 40 & 120 & 18 & 90 & 120 \\
9 & 40 & 180 & 19 & 90 & 180 \\
10 & 60 & 30 & - & - & - \\
\hline
\end{tabular}

\subsection{Evaluation of Carbonation Degree}

In order to evaluate carbonation degree of steelmaking slag and efficiency of absorbing $\mathrm{CO}_{2}$ by the slag, HCT-1/2 differential thermal analyzer (Henven Scientific Instument Factory, Beijing, China) was adopted. In the test, the crucible weighed $m_{0}$, the weight of the crucible plus the slag sample was $m_{1}$, and then weight of the slag sample was $m_{1}$ minus $m_{0}$.

The end temperature for the TGA test was $1000^{\circ} \mathrm{C}$, and heating rate was $10{ }^{\circ} \mathrm{C} / \mathrm{min}$; after the end temperature was achieved, the sample was held at that temperature for $3 \mathrm{~min}$. Because $\mathrm{HJ}$ thermal analysis software can record temperature, thermo-gravimetry and differential thermal analysis curve synchronously, it is convenient to determine the thermal characteristics of the slag.

Slag weight loss can be obtained from the thermogravimetric analysis curve, which mainly include three parts, free water evaporation in the temperature range of $25-105{ }^{\circ} \mathrm{C}$, organic carbon loss and magnesium carbonate decomposition in the temperature scope of $105-500{ }^{\circ} \mathrm{C}$, between $500{ }^{\circ} \mathrm{C}$ and $1000{ }^{\circ} \mathrm{C}$, calcium carbonate decomposition occurs. Carbonation degree can be evaluated with the Equations (1) and (2) referred in literature [9].

$$
\begin{gathered}
\eta_{\mathrm{CD}}=\frac{\frac{\mathrm{CO}_{2}(\mathrm{wt} . \%)}{1-\mathrm{CO}_{2}(\mathrm{wt} . \%)} \times \frac{M W_{\mathrm{Ca}}(\mathrm{kg} / \mathrm{mol})}{\mathrm{MW_{ \textrm {CO } }}(\mathrm{kg} / \mathrm{mol})}}{\mathrm{Ca}_{\text {total }}(\mathrm{kg} / \mathrm{kg})} \times 100 \% \\
\mathrm{CO}_{2}(\text { wt. } \%)=\frac{\left.\Delta m_{\left(500{ }^{\circ} \mathrm{C}-1000\right.}{ }^{\circ} \mathrm{C}\right)}{m_{105}{ }^{\circ} \mathrm{C}} \times 100 \%
\end{gathered}
$$

where $\mathrm{Ca}_{\text {total }}$ represents the content of element calcium in slag, $\%, m_{105}{ }^{\circ} \mathrm{C}$ denotes the weight of slag when heated to $105^{\circ} \mathrm{C}, \mathrm{mg}, \Delta m_{\left(500{ }^{\circ} \mathrm{C}-1000{ }^{\circ} \mathrm{C}\right)}$ denotes steelmaking slag weight loss when heated from $500{ }^{\circ} \mathrm{C}$ to $1000{ }^{\circ} \mathrm{C}, \mathrm{mg}, \eta_{\mathrm{CD}}$ denotes carbonation degree of slag, $\%$. 


\section{Results and Discussion}

\subsection{Characteristics of Slag Sample}

The slag sample contains $55.3 \% \mathrm{CaO}$, of which $10.6 \%$ is free $\mathrm{CaO}, 29.6 \%$ is a Ca-aluminate compound $\left(\mathrm{Ca}_{3} \mathrm{Al}_{2} \mathrm{O}_{6}\right)$ and $15.1 \%$ is Ca-silicates $\left(5.7 \% \mathrm{CaSiO}_{3}\right.$ and $\left.9.4 \% \mathrm{Ca}_{2} \mathrm{SiO}_{4}\right)$.

Specific surface areas of the raw slag sample change from $0.51 \mathrm{~m}^{2} / \mathrm{g}$ to $1.57 \mathrm{~m}^{2} / \mathrm{g}$, depending on the particle sizes. The specific areas of carbonated slag samples vary from $7.56 \mathrm{~m}^{2} / \mathrm{g}$ to $12.78 \mathrm{~m}^{2} / \mathrm{g}$ with the carbonation time increasing at $25{ }^{\circ} \mathrm{C}$. The results can be explained by the slag fragmentation model [18]; in other words, during the carbonation reaction process, carbonate calcium produced in slag surface area is peeling from the matrix by stirring, and causing increases of the initial slag surface area. SEM images of the steelmaking slag carbonated at different temperatures and reaction times are shown in Figure 2.

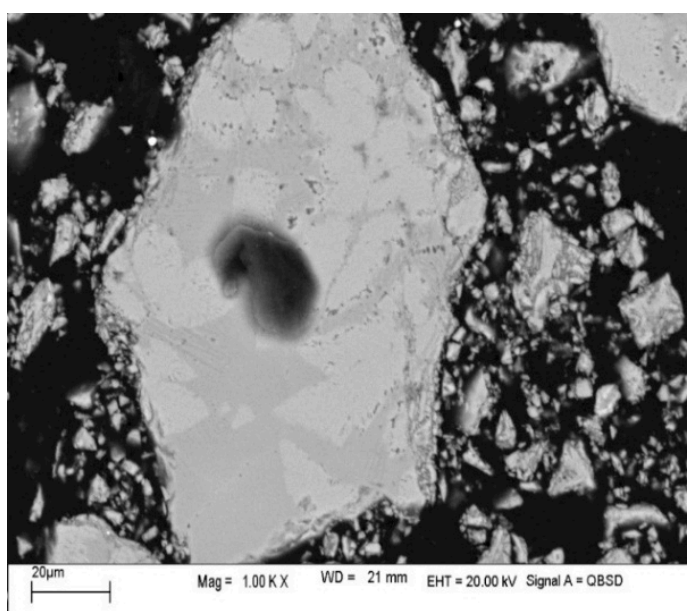

(a)

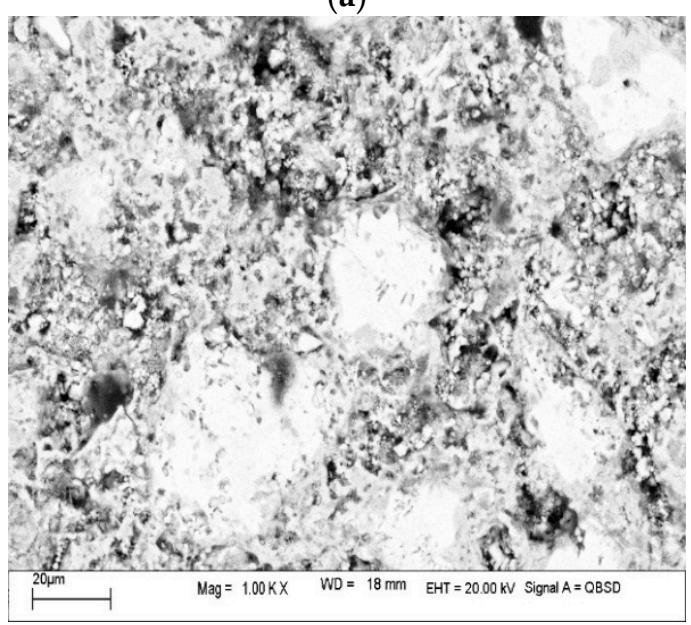

(c)

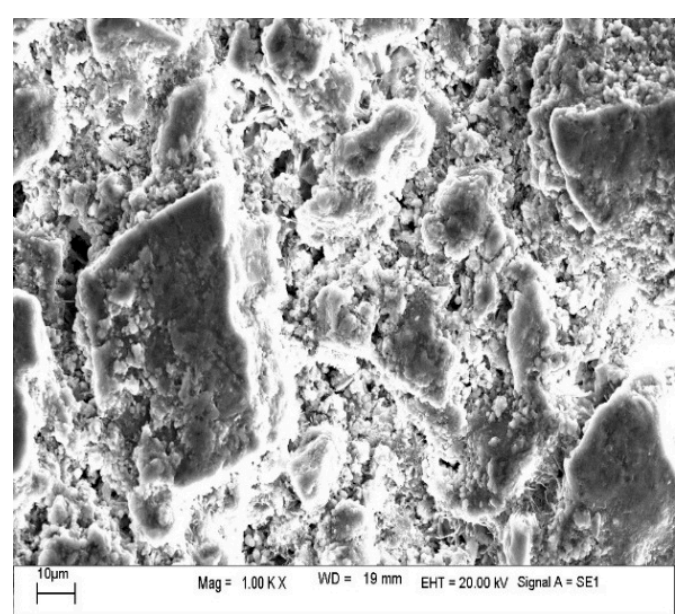

(b)

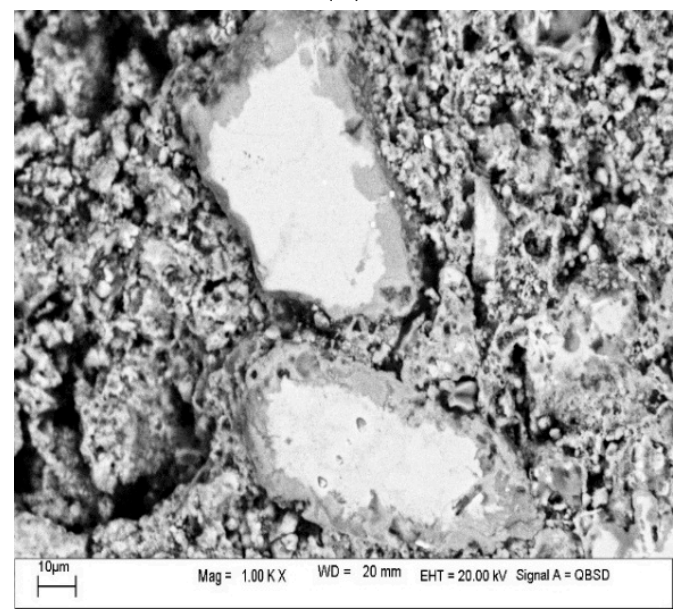

(d)

Figure 2. Steelmaking slag morphology before and after carbonation process: (a) before carbonation; (b) for $30 \mathrm{~min}$ at $60^{\circ} \mathrm{C}$; (c) $90 \mathrm{~min}$ at $60^{\circ} \mathrm{C}$; (d) $90 \mathrm{~min}$ at $90^{\circ} \mathrm{C}$.

\subsection{Effect of Carbonation Time on Mineralogical Phases Containing Calcium}

The effect of the carbonation time on the content of the main mineralogical phases in the slag sample is shown in Figure 3. Clearly, the peak intensity of the calcite phase increases when the carbonation time increases from $30 \mathrm{~min}$ to $60 \mathrm{~min}$, but after that, if extending carbonation time, the peak intensity of the calcite phase decreases. The peak intensity of the calcium aluminate phase decreases 
with the carbonation time increasing. This is because the calcium aluminate absorbs carbon dioxide dissolved in water, and the Ca-silicate phase, such as wollastonite, also reacts with carbon dioxide.
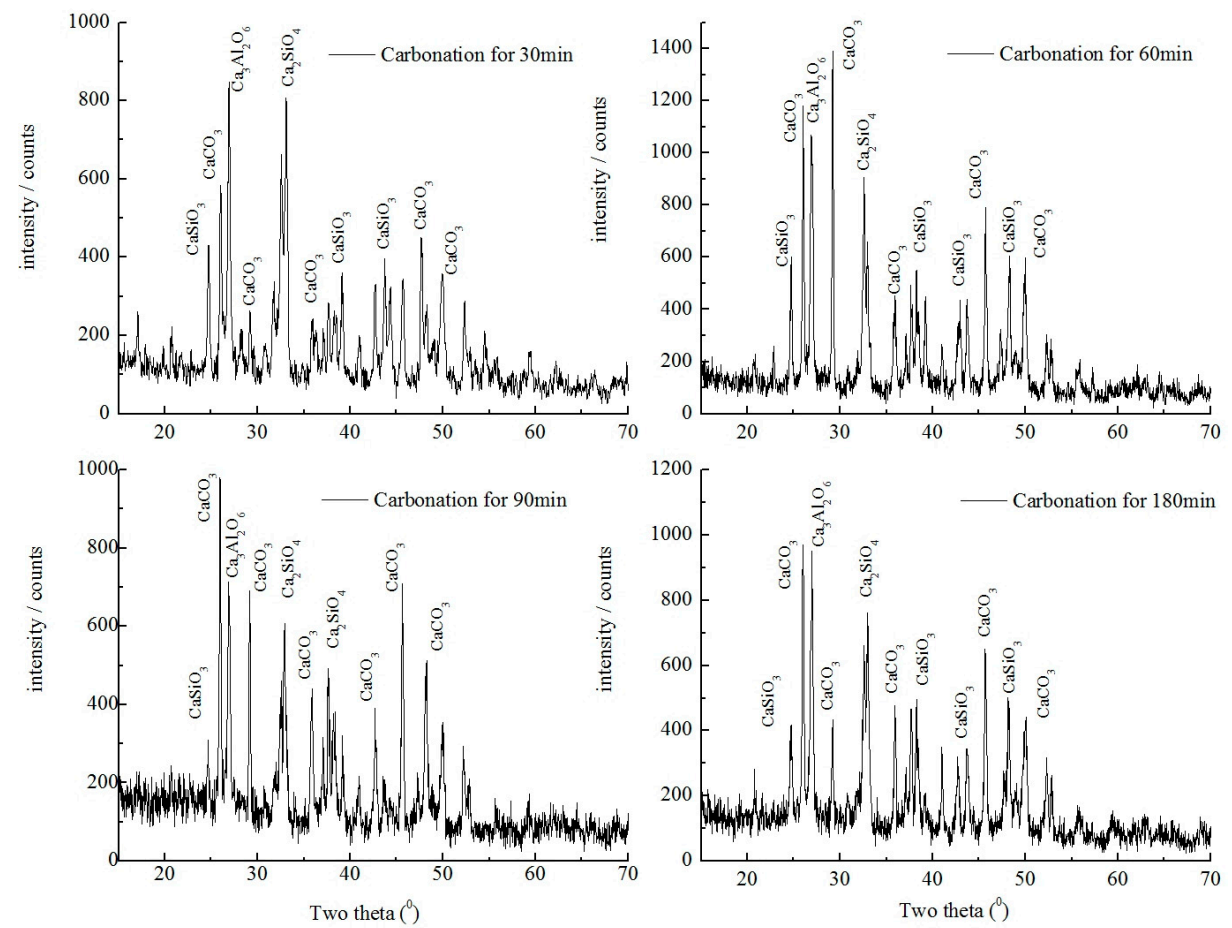

Figure 3. Effect of carbonation time on mineralogy phases containing calcium.

Quantitative XRD analysis of the slag has a better correlation with chemical test results [16]. Figure 4 describes the effect of reaction time on the carbonation degree contribution rate for calcium-related phases. It is apparent that the calcite content in slag increases from $15.34 \%$ to $25.47 \%$ when the carbonation time increases from $30 \mathrm{~min}$ to $90 \mathrm{~min}$. The calcite content in slag increases to $26.78 \%$ when expanding to an additional $90 \mathrm{~min}$, and the optimum reaction time can take place at $90 \mathrm{~min}$. The carbonation time is less than $90 \mathrm{~min}$, and the carbonation reaction cannot be allowed to complete. If the carbonation time is more than $90 \mathrm{~min}$, the reaction kinetic condition is worse because the carbonate calcium production is coated on the surface of the slag, which hinders the carbonation degree from increasing after $90 \mathrm{~min}$.

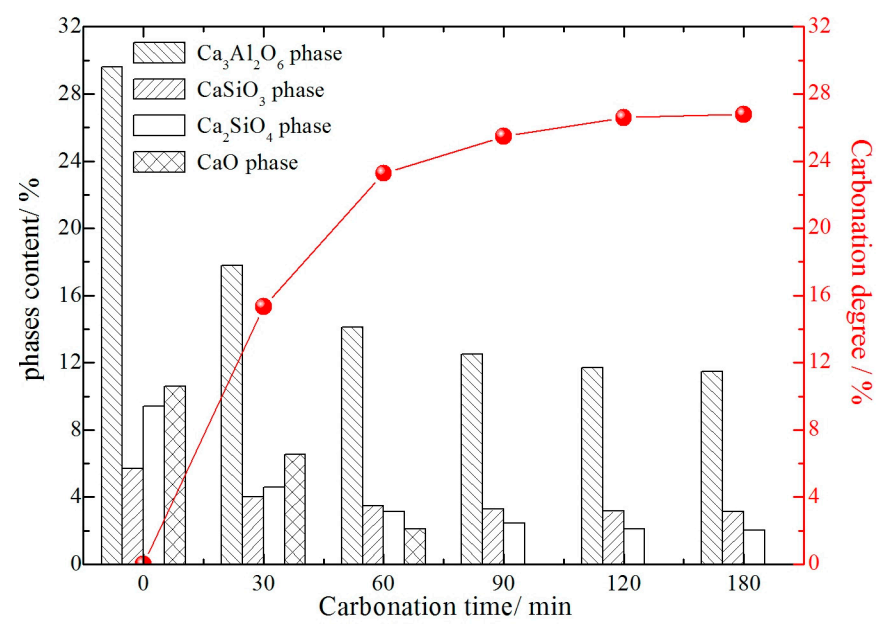

Figure 4. Effect of carbonation time on mineralogical phase content of slag carbonated at $60^{\circ} \mathrm{C}$. 
From Figure 4, one can see that the content of $\mathrm{Ca}_{3} \mathrm{Al}_{2} \mathrm{O}_{6}$ in the slag decreases from $29.6 \%$ to $17.79 \%$ when the slag is carbonated for $30 \mathrm{~min}$. When the carbonation time increases from $90 \mathrm{~min}$ to $180 \mathrm{~min}$, the content decreases from $12.51 \%$ to $11.49 \%$. Clearly, almost $40 \%$ of the $\mathrm{Ca}_{3} \mathrm{Al}_{2} \mathrm{O}_{6} \mathrm{can}$ be carbonated in the first $30 \mathrm{~min}$, and $8.15 \%$ of the $\mathrm{Ca}_{3} \mathrm{Al}_{2} \mathrm{O}_{6}$ will be carbonated in the next $60 \mathrm{~min}$. As for the calcium-silicate phase, the $\mathrm{CaSiO}_{3}$ content sharply decreases from $5.7 \%$ to $3.28 \%$ when the slag is carbonated for $90 \mathrm{~min}$, and further decreases to $3.14 \%$ after an additional $90 \mathrm{~min}$; the $\mathrm{CaSiO}_{3}$ conversion rate is $42.46 \%$ in the first $90 \mathrm{~min}$, and only $4.3 \%$ in the additional 90 min carbonation time. $\mathrm{Ca}_{2} \mathrm{SiO}_{4}$ has similar carbonation behavior to $\mathrm{CaSiO}_{3}$. In the first $30 \mathrm{~min}$ of carbonation time, the content of $\mathrm{Ca}_{2} \mathrm{SiO}_{4}$ in the slag decreases from $9.4 \%$ to $4.6 \%$; when the carbonation time increases from $90 \mathrm{~min}$ to $180 \mathrm{~min}$, the phase content decreases from $2.45 \%$ to $2.02 \%$. In the first $30 \mathrm{~min}$ of carbonation, $51.1 \%$ of the $\mathrm{Ca}_{2} \mathrm{SiO}_{4}$ is carbonated, and only $17.5 \%$ of the $\mathrm{Ca}_{2} \mathrm{SiO}_{4}$ is carbonated in the next 60 min of carbonation. For free lime in the raw slag sample, after 60 min of carbonation all initial $10.6 \%$ of free lime is carbonated.

\subsection{Effect of Carbonation Temperature on Mineralogical Phases Containing Calcium}

In order to analyze the effect of carbonation temperature on the carbonation degree and slag phase conversion, TGA-DSC (Netzsch, Gerätebau, Germany) tests were conducted on the slag carbonated, and TGA analysis results at different reaction temperatures are shown in Figure 5.

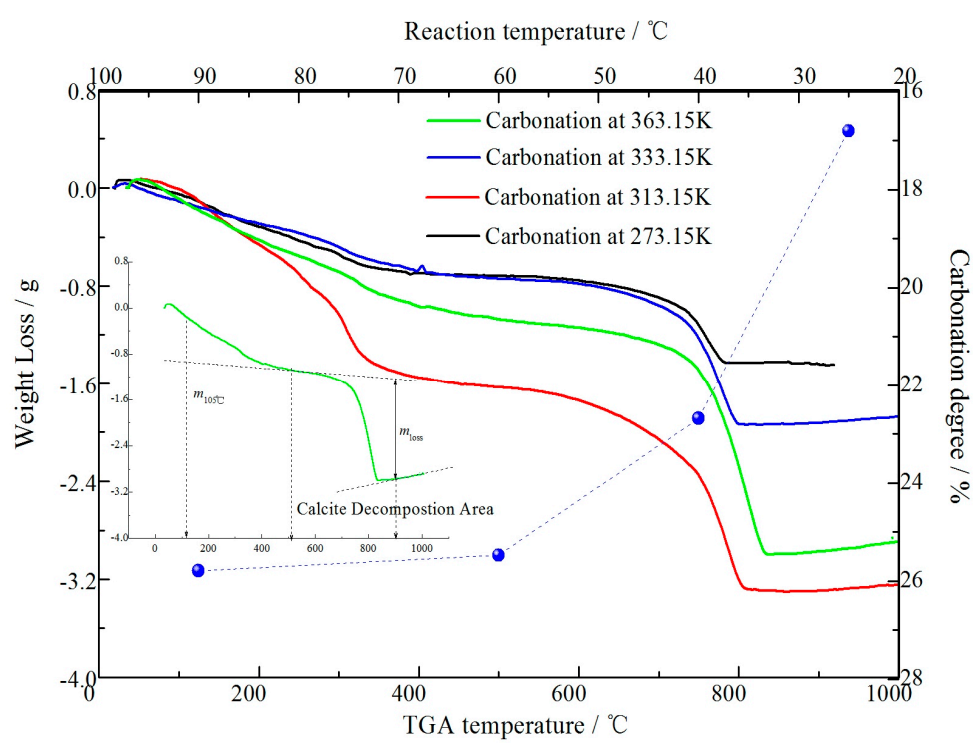

Figure 5. Effect of temperature on carbonation degree for steelmaking slag carbonated for $90 \mathrm{~min}$.

First, $7.95 \mathrm{~g}$ of steelmaking slag after $90 \mathrm{~min}$ of carbonation at $25^{\circ} \mathrm{C}$ was analyzed. The weight loss of the sample is $10.1 \%$ when the heating temperature increases from $500{ }^{\circ} \mathrm{C}$ to $1000{ }^{\circ} \mathrm{C}$; the carbonation degree calculated by Equation (1) is then $18.5 \%$ at $25^{\circ} \mathrm{C}$. The weight loss at $40{ }^{\circ} \mathrm{C}$ is $14.5 \%$, and the carbonation degree is $27.9 \%$, and the weight loss at $60{ }^{\circ} \mathrm{C}$ is $17.2 \%$, and the carbonation degree is $33.4 \%$. The weight loss at $90{ }^{\circ} \mathrm{C}$ is $15.2 \%$, and carbonation degree is $29.5 \%$. It can be concluded that the optimum temperature for maximum carbonation efficiency is about $60{ }^{\circ} \mathrm{C}$, due to the contradicting effects of temperature on the carbonation kinetics and solubility of calcium-related minerals in the water.

Obviously, at ambient reaction temperature and with $90 \mathrm{~min}$ of reaction time, the contents of calcite, $\mathrm{Ca}_{3} \mathrm{Al}_{2} \mathrm{O}_{6}, \mathrm{CaSiO}_{3}$ and $\mathrm{Ca}_{2} \mathrm{SiO}_{4}$ in the slag are $16.8 \%, 18.9 \%, 4.3 \%$ and $6.3 \%$, respectively in Figure 6. Calcite in the slag increases from $22.68 \%$ to $25.47 \%$ when the reaction temperature increases from $40{ }^{\circ} \mathrm{C}$ to $60{ }^{\circ} \mathrm{C}$. The calcite content increases to $25.79 \%$ when the carbonation temperature rises to $90{ }^{\circ} \mathrm{C}$. The $\mathrm{Ca}_{3} \mathrm{Al}_{2} \mathrm{O}_{6}$ content in slag decreases from $14.8 \%$ to $12.49 \%$ when the carbonation temperature 
increases from $40{ }^{\circ} \mathrm{C}$ to $60{ }^{\circ} \mathrm{C}$, but it increases to $13.75 \%$ when the reaction temperature rises to $90^{\circ} \mathrm{C}$. This is because there is a reversal relationship between $\mathrm{CO}_{2}$ solubility in water and the reaction temperature. $\mathrm{Ca}_{3} \mathrm{Al}_{2} \mathrm{O}_{6}$ has a lower conversion rate with a lower carbon dioxide solubility at a higher carbonation temperature. The contents of $\mathrm{CaSiO}_{3}$ and $\mathrm{Ca}_{2} \mathrm{SiO}_{4}$ decrease from $2.9 \%$ to $2.72 \%$ and $5.1 \%$ to $3.48 \%$, respectively. When the carbonation temperature increases from $40{ }^{\circ} \mathrm{C}$ to $60{ }^{\circ} \mathrm{C}$, the contents of the two phases increase to $3.11 \%$ and $5.18 \%$, respectively.

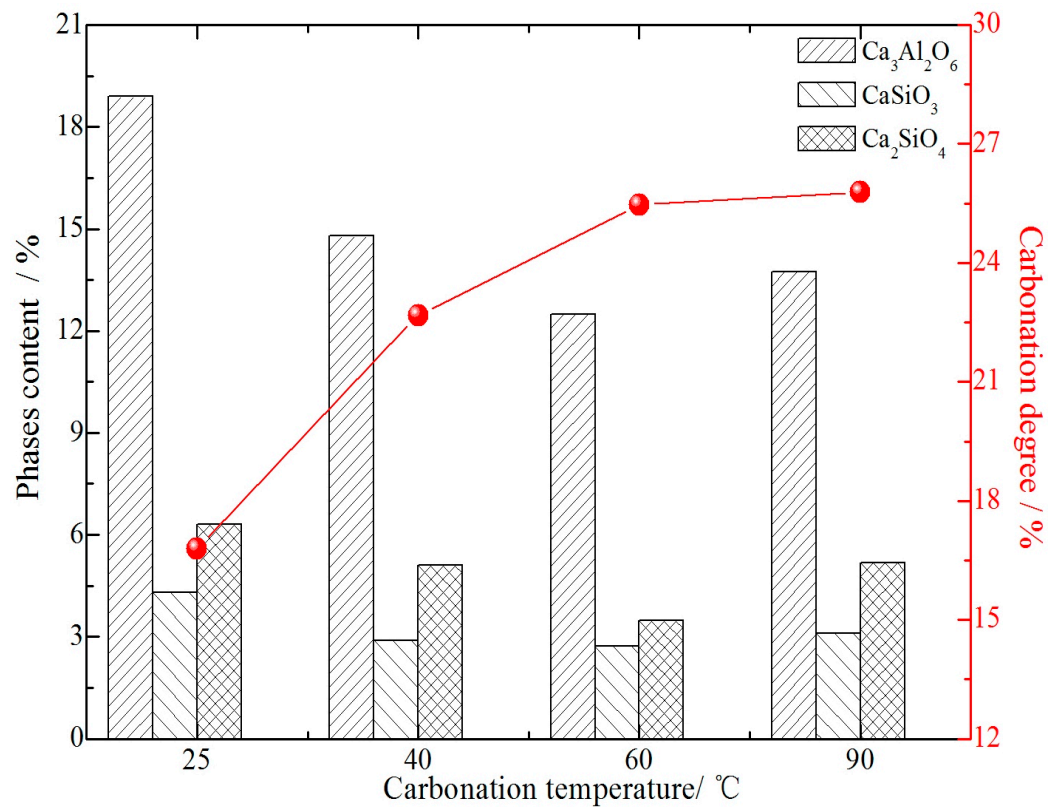

Figure 6. Effect of temperature on content of mineralogical phases of slag carbonated for $90 \mathrm{~min}$.

\section{Conclusions}

The carbonation process was experimentally tested on a steelmaking slag sample under the conditions of a ratio of liquid to solid at $20 \mathrm{~mL} / \mathrm{g}$, a $5 \mathrm{~g}$ sample weight and particle sizes from $38 \mu \mathrm{m}$ to $75 \mu \mathrm{m}$. The optimum carbonation temperature and reaction time are $60^{\circ} \mathrm{C}$ and $90 \mathrm{~min}$, respectively. The maximum carbonation degree is about $26.78 \%$. The conversion rates of $\mathrm{Ca}_{3} \mathrm{Al}_{2} \mathrm{O}_{6}$ phase, $\mathrm{CaSiO}_{3}$, $\mathrm{Ca}_{2} \mathrm{SiO}_{4}$ and free $\mathrm{CaO}$ are about $40 \%, 42.46 \%, 51 \%$ and $100 \%$, respectively.

Acknowledgments: This research was supported by grants from The National Natural Science Foundation of China (No.51304053), Jiangxi University of Science and Technology doctoral start-up fund (No.3401223181).

Author Contributions: Zhang Huining and Lu Yongming conceived of and designed the experiments. Dong Jianhong performed the experiments. Gan Lei and Tong Zhifang analyzed the data and discussed the results. All the authors participated in writing this paper.

Conflicts of Interest: The authors declare no conflict of interest.

\section{References}

1. Seifritz, W. $\mathrm{CO}_{2}$ disposal by means of silicates. Nature 1990, 345, 486. [CrossRef]

2. Lackner, K.S.; Wendt, C.H.; Butt, D.P.; Joyce, E.L.; Sharp, D.H. Carbon Dioxide Disposal in Carbonate Minerals; Los Alamos National Laboratory: Los Alamos, NM, USA, 1995.

3. Huijgen, W.J.J.; Comans, R.N.J. Carbon Dioxide Sequestration by Mineral Carbonation: Literature Review; Energy Research Centre of the Netherlands: Petten, The Netherlands, 2003.

4. Huijgen, W.J.J.; Comans, R.N.J. Carbonation of steel slag for $\mathrm{CO}_{2}$ sequestration: Leaching of products and reaction mechanisms. Environ. Sci. Technol. 2006, 40, 2790-2796. [CrossRef] [PubMed]

5. Kodamaa, S.; Nishimotob, T.; Yamamoto, N.; Yogo, K.; Yamada, K. Development of a new pH-swing $\mathrm{CO}_{2}$ mineralization process with a recyclable reaction solution. Energy 2008, 33, 776-784. [CrossRef] 
6. Huijgen, W.; Witkamp, G.; Comans, R. Mineral $\mathrm{CO}_{2}$ Sequestration by Steel Slag Carbonation. Environ. Sci. Technol. 2005, 39, 9676-9682. [CrossRef] [PubMed]

7. Huijgen, W.; Ruijg, G.; Comans, R.; Witkamp, G. Energy Consumption and $\mathrm{Net}^{\mathrm{CO}_{2}}$ Sequestration of Aqueous Mineral Carbonation. Ind. Eng. Chem. Res. 2006, 45, 9184-9194. [CrossRef]

8. Pan, S.Y.; Chiang, P.C.; Chen, Y.H.; Tan, C.S.; Chang, E.E. Ex situ $\mathrm{CO}_{2}$ capture by carbonation of steelmaking slag coupled with metalworking wastewater in a rotating packed bed. Environ. Sci. Technol. 2013, 47, 3308-3315. [PubMed]

9. Chang, E.E.; Pan, S.Y.; Chen, Y.H.; Chu, H.W.; Wang, C.F.; Chiang, P.C. $\mathrm{CO}_{2}$ Sequestration by Carbonation of Steelmaking Slags in an Autoclave Reactor. J. Hazard. Mater. 2011, 195, 107-114. [CrossRef] [PubMed]

10. Chang, E.E.; Chiu, A.C.; Pan, S.Y.; Chen, Y.H.; Tan, C.S.; Chiang, P.C. Carbonation of Basic Oxygen Furnace Slag with Metalworking Wastewater in a Slurry Reactor. Int. J. Greenh. Gas Control 2013, 12, 382-389. [CrossRef]

11. Van Zomeren, A.; van der Laan, S.R.; Kobesen, H.B.A.; Huijgen, W.J.J.; Comans, R.N.J. Changes in Mineralogical and Leaching Properties of Converter Steel Slag Resulting from Accelerated Carbonation at Low $\mathrm{CO}_{2}$ Pressure. Waste Manag. 2011, 31, 2236-2244. [CrossRef] [PubMed]

12. Eloneva, S.; Teir, S.; Salminen, J.; Fogelholm, C.; Zevenhove, R. Steel Converter Slag as a Raw Material for Precipitation of Pure Calcium Carbonate. Ind. Eng. Chem. Res. 2008, 47, 7104-7111. [CrossRef]

13. Lekakh, S.N.; Robertson, D.G.C.; Rawlins, C.H.; Richards, V.L.; Peaslee, K.D. Investigation of a Two-Stage Aqueous Reactor Design for Carbon Dioxide Sequestration Using Steelmaking Slag. Metall. Mater. Trans. $B$ 2008, 39B, 484-492. [CrossRef]

14. Yokoyama, S.; Sato, R.; Muhd, N.; Nik, H.B.M.N.; Umemoto, M. Behavior of $\mathrm{CO}_{2}$ Absorption in Wet-grinding of Electronic Arc Furnace Reducing Slag by Vibration Ball Mill. ISIJ Int. 2010, 50, 482-489. [CrossRef]

15. Tan, C.; Chen, J. Absorption of carbon dioxide with piperazine and its mixtures in a rotating packed bed. Sep. Purif. Technol. 2006, 49, 174-180. [CrossRef]

16. Taylor, J.C. Computer programs for standardless quantitative analysis of minerals using the full powdered diffraction profile. Powder Diffr. 1991, 6, 2-9. [CrossRef]

17. Colin, R.W.; Taylor, C.J.; Cohen, D.R. Quantitative mineralogy of sandstones by X-ray diffractometry and normative analysis. J. Sedim. Res. 1999, 69, 1050-1062.

18. Edwards, B.F.; Cai, M.; Han, H.T. Rate equation and scaling for fragmentation with mass loss. Phys. Rev. A 1990, 41, 40-43. [CrossRef]

(C) 2016 by the authors; licensee MDPI, Basel, Switzerland. This article is an open access article distributed under the terms and conditions of the Creative Commons Attribution (CC-BY) license (http:/ / creativecommons.org/licenses/by/4.0/). 